\title{
STRATEGIES FOR PROGRESS: LOOKING FOR FIRM GROUND
}

\author{
Ann Corsellis \\ a.corsellis@ntlworld.com \\ Chartered Institute of Linguists, UK
}

\begin{abstract}
Over the last thirty years, there have been various and increasing efforts made to establish effective and consistent public service interpreting and translation. Good progress has been made but there are impasses. This paper attempts to stand back and look objectively at where, and more importantly how, we might proceed from here.

This could be said to be a turning point for legal interpreting for two reasons. Firstly, enough time has elapsed for us to copy our scientific colleagues, who view the process of exploring and eliminating unsatisfactory approaches overtly, so that what does not work is recognised and discarded. Secondly, this process of exploration has enabled us to clarify and define what does work in order to focus our energies and take matters forward.
\end{abstract}

\section{Resumen}

A lo largo de estos últimos treinta años se han producido diversos y crecientes esfuerzos para establecer unos servicios de traducción e interpretación en los servicios públicos que fuesen eficaces y coherentes. Aunque se han realizado importantes progresos, existe cierto estancamiento. Este artículo pretende alzar la vista y proporcionar una visión objetiva sobre hacia dónde, pero sobre todo cómo se puede proceder a partir de este momento.

Cabría decir que la interpretación judicial se encuentra en un punto de inflexión por dos razones. En primer lugar, ha transcurrido tiempo suficiente para ser capaces de imitar a nuestros colegas científicos, que abordan de manera abierta el proceso de evaluación y eliminación de planteamientos insatisfactorios, identificando y descartando lo que no funciona. En segundo lugar, este proceso de exploración nos ha permitido aclarar y definir lo que sí funciona con el fin de centrar bien nuestras energías y avanzar. 
Keywords: Legal interpreting. Community of practice. Registers. Assessment. Planning.

Palabras clave: Interpretación judicial. Comunidad de práctica. Registros. Evaluación. Planificación.

Manuscript received on July 7, 2014

and accepted for publication on September 12, 2014. 


\section{Introduction}

Turning points can only be effective if they are taken strategically on the basis of adequate information. The last twenty or thirty years have seen the development of a worthwhile body of evidence, based on both academic research and practical experience. This supports the clarification of three broad areas:

- aims, against a realistic appraisal of what exists

- which strategies have proved to be unhelpful, or only partly helpful, in reaching those aims

- which strategies have proved to be successful to a significant degree.

The development experience is producing in legal interpreters a genuine community of practice (D'Hayer 2013) with a growing professional self-confidence. There is an emerging core consensus, which allows for cultural differences in approaches by individual member states. At the same time, those working in the legal services have become aware of the role and identity of professional legal interpreters and translators (LITs). This has come about in large part through their experience of working with properly trained, qualified and experienced LITs, where they exist; doing their task with a dignified competence which complements their own.

\section{Clear aims}

There is a need to go back regularly to basics, to check that progress remains on track. The core principles of aims will, inevitably, be expanded in the light of experience but it could be said that a commonality of aims has evolved. That commonality of aims has an importance because the legal, health and social services of each country increasingly have to communicate with those in other countries; for example in prevention of terrorism and of trafficking drugs and people, and where medical and social matters cross national borders. An international consistency of basic standards and approaches is needed so that individual countries can have mutual trust in each other's interpreting and translation. 
In broad terms, the aims are threefold. They have all been described elsewhere (Hertog 2001, Hertog 2003, Corsellis 2008) and may be summarised, along with some crucial steps towards them, as follows:

\subsection{National, independent professional registers of public service interpreters and translators (PSITs)}

Professional registers are independent, not-for-profit, voluntary or statutory bodies which register, and make freely available, the details of individuals who have met their criteria and agree to profess/observe a specified code of conduct/ethics. The criteria include: qualifications at the recognised minimum graduate level; proven, relevant experience and security clearances. Standards are maintained through regular re-registration requirements. A register also administers transparent disciplinary procedures where breaches of its code are alleged. A register is not merely a database or a list.

The level and approach to professional assessment is at the core of a register. A current EU funded project, Qualitas, ${ }^{1}$ seeks to define and offer assessment strategies to colleagues in other member states, and to promote a consistency of qualifications across the EU. The project began by summarising the status quo, which showed an existing unevenness in developments, as can be seen from the EU country profiles on the Qualitas website. It will take time to bring about the consistency required. The project Building Mutual Trust $1^{2}$ developed freely downloadable training materials, to offer colleagues examples in order to assist in their course provision.

In the long-term, there is a need for reliable and consistent national PSIT registers, which may be accessed with confidence from other countries. This, in its turn, will require careful thought and planning on such matters as disciplinary procedures where, for example, a LIT from country A is alleged to have breached professional codes in country B.

In the shorter term, it is envisaged that a database will be set up on the e-justice portal. A pilot LIT Search project has just begun, coordinated by Lessius Hogeschool, and is due to report in October 2015. It is looking, presumably in the first instance, at databases as well as registers and exploring the modalities and practical features that would be needed and how these might link between member states.

1. www.qualitas-project.eu

2. www.buildingmutualtrust.eu 


\subsection{National professional structures for PSITs}

PSITs also need the protection of structures normal to any professions, which include national examination bodies, membership organisations to give support, and trade unions. These are at various stages of development in many member states. Austria, the Czech Republic, Poland and the UK have registers based upon qualifications, while others such as Spain are in the process of development.

EULITA, the European Legal Interpreters and Translators Association, was established through an EU project to act as a focus for these developments. ${ }^{3}$

\subsection{National guidelines for good practice for those employed by the public services and working across languages and cultures}

PSITs do not work in a vacuum. Their colleagues in other professions, with whom they work, need to be adept at accommodating both the interpreting process and the bicultural nature of the interaction, and be professionally accountable for those skills. The Directive 64/2010/EU about legal interpreting is specific about the requirements to train those working in legal systems in these skills. The outcomes of the EU project Building Mutual Trust 2 have begun this by offering freely downloadable multilingual basic training videos. ${ }^{4}$

As can be seen from the Country Profile section of the Qualitas project mentioned above, alongside the formal EU funded projects, committed work is taking place in each member state, at varying stages of development, including training courses, assessments and practice. Many, however, are finding that their routes to what they wish to achieve are blocked. This can be due, for example, to lack of political will and consequent inadequate provision of resources for training, accreditation and employment.

\section{Impasses}

The main component parts have been carefully explored, defined and recorded in, inter alia, Aequitas and Aequalitas: two EU funded projects designed to define, and then share, the necessary minimum standards of training and good practice for legal interpreters for all member states. One would think it was simply a matter of following their recommendations.

Why then cannot they always be satisfactorily implemented? Over ten years ago, the recommendations of Aequalitas (EU project Grotius programme

\footnotetext{
3. www.eulita.eu

4. www.buildingmutualtrust.eu
} 
2001/GR8/015) (Hertog 2003) included a chapter by this author for a simple three-phase cycle of a development spiral, which would have been cost-effective to apply. This may be summarised as:

1. Establish foundations, in terms of:

- management structures

- assessing present and future demand

- beginning training trainers, interpreters and legal services

- setting up remedial training for students requiring it to start training next year

- setting out systems for employment, deployment, supervision and support.

2. Begin annual systems for:

- assessment of trainers, interpreters and legal services

- professional registration for those who qualify

- putting in place employment and deployment systems for those registered

3. Propel spiral of informed development, while increasing range of languages and numbers, through on-going:

- training

- assessments

- registration

- supervised and supported employment of skills sets.

It was perhaps naive to think that it could, or would, be done in some form. There was a general, if unspoken, expectation that such a straightforward development would be implemented in the face of pressing social need.

\section{Negative research findings are a positive}

The reasons why things are not done, or done in a sub-standard way, can be more interesting than why they are. Scientists are crisply overt about negative findings. They make rigorous efforts to identify and record approaches that do not work out so that, through a process of elimination, they can find what does work and not waste time on fruitless exercises. It is useful to know when to cut your losses.

Maybe we should adopt the generality of the scientific approach. This might be a good moment to take a cold, objective look at what approaches have been of limited or no use, so that we can have the confidence to move on to what might be of more use. This can only be done in general terms 
because of differences in countries and how they manage social change, but even then this might aid a helpful thought process. Timing is also a consideration because what has no purchase now may have that at a later stage. Care should also be taken to use this process as a reality check of the world as it is, and put that to good use without becoming over-cynical.

What, then, are some of the approaches to constructive progress which have been proved to be unhelpful?

\subsection{Governments}

The following extract from a Fair Trials International report sets out six important and related EU Directives:

The fundamental right to a fair trial is enshrined in EU law but it does not receive the same level of protection in every European country.

At the end of 2009 the European Union adopted a defence rights "Roadmap", paving the way for fair trial rights to be better protected throughout Europe. As of April 2014, three new laws have been adopted under the Roadmap and three more have been proposed by the Commission.

The first Directive, on the right to translation and interpretation, means that nobody will be denied a fair trial because they do not speak or understand the language of the country in which they are arrested. The Directive was adopted in October 2010, and should have been implemented by member states by October 2013.

The second Directive, on the right to information in criminal proceedings, was adopted in May 2012 and must be implemented by member states in time for June 2014. The Directive means that anyone arrested in the EU will be supplied with key information about their basic legal rights and the charges against them in a language they understand, without which they cannot effectively prepare for trial.

The third Directive, on the right to access a lawyer following arrest and to communicate with a consular official or nominated person (such as a relative), was adopted in October 2013. Most significantly, the Directive guarantees people facing criminal proceedings the right to be advised by a lawyer - from arrest through to a case's conclusion. ${ }^{5}$

This clearly illustrates the context of the Directive relating the interpreting. It is not enough only to be able to communicate between languages. To have access to justice one also needs access, through that communication, to information and legal assistance operating within a robust and reliable legal system. The uneven background of the existing legal structures are admirably summarised by Fair Trials International, after the report above, in an

5. http://www.fairtrials.org/justice-in-europe/eu-defence-rights/ 
interactive map that shows which member states are implementing the relevant EU Directives and how. ${ }^{6}$

The Fair Trials statement concludes with three coming Directives and underlines the work yet to be done to implement all six:

Meetings with members of our Legal Experts Advisory Panel during 2013

have demonstrated that member states have a lot of work to do in order to make the rights set out in these three directives a reality for suspects and defendants facing criminal proceedings.

In November 2013, the Commission published a new package of three proposed directives, on the right to legal aid, the presumption of innocence and procedural safeguards for children facing criminal proceedings. Negotiations on these remaining "Roadmap" measures are expected to commence in late 2014.

Following these Directives, there has been a sort of expectation that "they", at government level, would take on board responsibility for legal interpreting and translation because of the legal requirements, pressing social need and public good. In fact, responses from governments have been variable in terms of solid, practical delivery, despite expressions of good will which may or may not be sincere.

Governments differ between countries and between elections, guided by their innate philosophies, cultures and experiences. This was recognised by Ozolins (1998) in a prescient paper he gave at the second Critical Link conference. Governments differ because they are made up of people, elected by other people, in the same way as our students differ. We learn to accommodate our students; to work with their assets, try to get round their shortcomings and nudge them forwards.

Perhaps these analytical skills should be applied in respect of our governments. They have to be asked for what they can deliver well. Equally importantly, but more difficult, is to divert them from unhelpful strategies, such as an inappropriate use of technology when excellent work has been done on its appropriate implementation in the AVIDICUS projects, ${ }^{7}$ whose rigorously detailed reports can be seen on their website. If used correctly, remote interpreting can assist in such situations as where witnesses are in another country or where children are better not in a court room, in routine matters such as bail hearings and perhaps more extensively. But caution should be used and

6. http://www.fairtrials.org/justice-in-europe

7. www.videoconference-interpreting.net 
the current AVIDICUS 3 project is looking carefully at implementation in practice.

How useful are governments in this context? This is explored by Sasso \& Malli (2004: 49):

As we can see, the current absence of political will can leave community interpreting in a flux, but simply enacting or pursuing a public policy agenda will not necessarily cure community interpreting of its ills. Perhaps the question is not whether the industry needs public policy, but whether it is, indeed, needed at this point in our evolution. Time may be better spent on clearly defining the professional structure and process of training, certification, enforcement, membership and role definition - a progression articulately stated in Holly Mikkelson's 1996 article "The Professionalisation of Community Interpreting".

This may well be true but there are things that only a government can do and are beyond the remit or power of the interpreting profession. Passing and implementing necessary legislation, guaranteeing the integrity of an independent legal system and providing adequate budgets to legal services, are crucial responsibilities of the state. What government can do beyond those basic responsibilities may have to be gauged on an individual basis.

\subsection{Lowering standards of training and practice}

The first question too often asked is not, "how well can we do this?" but "how little can we get away with?"

The unequivocal answer lies in the national and international minimum interpreting standards that have been painstakingly developed and published. It is abundantly clear that anything below $\mathrm{C} 2 / \mathrm{Cl}$ as set out by the Common European Framework of Reference for Languages (CEFR) ${ }^{8}$ levels of language skills may not produce accuracy of legal interpreting.

Sometimes pressures to reduce standards come from so way-out that they are breathtaking. One such taken forward in the UK is that public service personnel, such as monolingual police officers, can predict the linguistic complexity of a future assignment. It may be assumed that, based on their perception of the importance of the exchange, "interpreters" with minimal level language skills could be allocated to such events as community relations communications. There are even educational establishments which take money for training "interpreters" in a week, and have been known to award certificates of doubtful value.

8. www.coe.int/lang-CEFR 
One of the main stumbling blocks appears to be a lack of the decision makers' conceptual ability to recognise that there cannot be sufficient, suitably qualified legal interpreters in all the languages and locations needed by next week; coupled with the lack of management ability to plan and organise an incremental system to achieve that aim over a realistic time-scale, while making responsible arrangements to bridge the gaps in the short-term.

There is a significant difference between incremental levels of training towards a recognised professional qualification, and wasting resources on lower level short-term compromises that never become satisfactory long-term solutions. The engagement of trainees with lower level skills may be necessary in the short-term, where better solutions are not available, but for their sake and for their clients' sake, these arrangements must be surrounded by safeguards which include absolute transparency and not forgetting appropriate insurance cover.

Publications and circulations about PSIT contain litanies of evidence of failures where sub-standard levels of skills or practice have been applied. It is difficult to quantify with sufficient precision to make the exercise worthwhile, but it is self-evident that the accumulated costs of failure are likely to exceed the cost of getting it right in the first place. It can be revealing, however, to do a fairly simple costing of the results of inadequate or no interpreting such as lost court days, appeals and remands in custody, and look at how many legal interpreters could be trained for that sum.

\subsection{Outsourcing}

The logic is understandable but the math does not add up. Particularly in non-EU countries where most public services are commercialised, the notion that arrangements for PSIT can be handed over to a private company may seem logical. But that means that a worthwhile profit must be produced in a context where both the clients (the public services and the Other Language Speakers) normally have limited resources. Unless sufficient resources are allocated to the public services, this usually leads to lowering interpreting standards, working conditions and fees, which have had disastrous results. Since the introduction of outsourcing in the UK, over one thousand qualified legal interpreters have felt obliged to refuse to take work from the commercial companies involved.

Furthermore, professional accountability is weakened. Conflicts of interest abound where a commercial company takes on a multiplicity of roles, such as being both employer and regulatory body. Overall slippage of standards takes place swiftly and is difficult to recover from. 


\section{What is the firm ground?}

What then can be done to overcome the negative pressures, such as the examples above? There I would agree with Sasso \& Malli (2004), that the time and effort available would be best spent simply by building the profession. If a critical mass of qualified competent legal interpreters can be achieved, they would provide a viable alternative to short-term solutions and, equally importantly, be responsible for their own profession with sufficient weight to withstand, for example, any judiciary which lacks integrity and independence.

Who would do this? Where is the solid ground on which to build? Three such areas are suggested as a start:

1. PSITs themselves. They are intelligent, resourceful people who know their profession and are proud of it. They are learning to be collaborative and a community of practice is developing. They have the potential to work with others towards the common aims. A good example of this is the recently formed ENPSIT, the European Network for Public Service Interpreters and Translators. ${ }^{9}$

2. Front-line public services mostly appreciate both the need for good interpreting, and the skills sets needed to do it. While some doctors and so forth may still say that children and family members make satisfactory interpreters, even they are learning that is not the case. From their close contact with the public, they are beginning to understand the time it takes to learn an official language to a level where reliable communication can take place and that, in the meantime, assistance is required.

There is an increasing awareness of the risks of inadequate interpreting, not just to other language speakers but also to providers of public services themselves, who have a professional responsibility for their decisions and are accountable for them. Where those decisions are based on inaccurate information, because decisions have been made deliberately to engage sub-standard interpreting and translation, they are at risk: at risk from litigation and from disciplinary actions within their own professions.

The public service employees are therefore in an informed position to put pressure on their own authorities to fund, deploy and employ PSITs effectively. In many cases they appreciate the negative pressures legal interpreters are under, because they too are suffering from them.

9. www.enpsit.eu 
3. Academia has been relatively solid in this area. Their own protocols for standards have gone a good way to protecting standards for training PSITs and for research. Inevitably, there will be some papers written, and even given at conferences, which attempt to spin gold out of very little damp straw, but that is the way of things and they usually disappear in light of day and reality.

The best of academia knows how to pursue excellence with diligence, and should be in a position to bring that rigour to taking matters forward by example in all sectors of this field.

\section{Conclusions}

We have the confidence and experience to recognise and deflect non-productive strategies.

We have at least three increasingly firm areas on which to build. If those three were able to collaborate consistently on a local or regional basis, capacity building could take place in ways which would make the optimum use of energy and resources. National and international consistencies would follow.

Professional progress consists of a series of larger and smaller turning points. Each one should be subject to collective and constant evaluation, so that misjudgements can be spotted quickly and accommodations made to changing circumstances. The success of each one depends upon the soundness of the decisions and implementation of the one before it.

We have come a long way, and much of the going has been tough, but things are looking up. As a successful war leader said, at another turning point, "this is not the end. It is not even the beginning of the end. But it is, perhaps, the end of the beginning".

\section{References}

CorseluIS, Ann. (2008) Public Service Interpreting: the First Steps. Basingstoke: Palgrave Macmillan.

D'HAYER, Danielle. (2013) "Public service interpreter education: A multidimensional approach aiming at building a community of learners and professionals." In: Schäffner, Christina; Krzysztof Kredens \& Yvonne Fowler (eds.) 2013. Interpreting in a Changing Landscape. Amsterdam: John Benjamins, pp. 321-337.

Hertog, Erik (ed.) (2001) Aequitas: Access to Justice across Language and Culture in the EU. Antwerp: Lessius Hogeschool.

Hertog, Erik (ed.) (2003) Aequalitas: Equal Access to Justice Across Language and Culture in the EU. Antwerp: Lessius Hogeschool. 
OzOLINS, Uldis. (1998) "Communication Needs and Interpreting in Multilingual Settings: The International Spectrum of Response." In: Roberts, Roda; Silvana E.Carr; Diana Abraham \& Aideen Dufour (eds.) 1998. The Critical Link 2. Interpreters in the Community. Amsterdam: John Benjamins, pp. 21-34.

SASSO, Angela \& Kiran Malli. (2014) "Trying to Fit a Square Peg into a Round Hole. Is Community Interpreting Just Too Big for Public Policy? The Canadian Experience." FITISPos 1:1, pp. 42-50.

Webgraphy

QUALITAS. Assessing Legal Interpreting Quality through Testing and Certification. Electronic version: <http://www.qualitas-project.eu/>

Building Mutual Trust. A Framework Project for Implementing EU Common Standards in Legal Interpreting and Translation. Electronic version: <http:// www.buildingmutualtrust.eu/>

EULITA. European Legal Interpreters and Translators Association. Electronic version: <http://www.eulita.eu/>

FAIR TRIALS INTERNATIONAL. Electronic version: <http://www.fairtrials.org/>

AVIDICUS. Electronic version: <http://www.videoconference-interpreting.net/>

COUNCIL OF EUROPE. Common European Framework of Reference for Languages: Learning, Teaching, Assessment (CEFR). Electronic version: <http://www. coe.int/t/dg4/linguistic/cadrel_en.asp>

ENPSIT. Europees network voor social tolken en vertalen. Electronic version: <http://www.enpsit.eu/>

\section{BIONOTE / NOTA BIOGRÁFICA}

Ann Corsellis OBE is a Vice President and Honorary Fellow of Chartered Institute of Linguists UK. She coordinated projects for the development of systems for the selection, training, assessment, good practice and registration of public service interpreters in the UK and was the first chairman of the National Register of Public Service Interpreting. She coordinated the first EU project on legal interpreting and participated in related subsequent EU projects. Her publications include Public Service Interpreting: the First Steps (Palgrave Macmillan, 2008).

Ann Corsellis, a la que se ha otorgado la Orden del Imperio Británico, es vicepresidenta y miembro honorario del Chartered Institute of Linguists (equivalente al Real Instituto de Lingüistas británico). Ha coordinado proyectos para el desarrollo de sistemas de selección, formación, evaluación, 
buenas prácticas y registro de intérpretes para los servicios públicos en el Reino Unido. Igualmente, fue la primera presidenta del Registro Nacional de Interpretación para los Servicios Públicos. Coordinó el primer proyecto de la Unión Europea sobre interpretación judicial y participó en sucesivos proyectos europeos de la misma naturaleza. Entre sus publicaciones, cabe destacar el libro Public Service Interpreting: the First Steps, publicado por la editorial Palgrave Macmillan en 2008 (traducido en España por Carmen Valero Garcés y Rosa Cobas Álvarez en 2010 como Traducción e interpretación en los servicios públicos. Primeros pasos, publicado por la editorial Comares). 